\title{
The Ordovician Quebrada Grande Formation, Cordón de Lila (Antofagasta Region, northern Chile): stratigraphic and paleogeographic significance
}

\author{
Javier González \\ Hans Niemeyer
}

Juan L. Benedetto

Edsel D. Brussa
Departamento de Ciencias Geológicas, Universidad Católica del Norte, Av. Angamos 0610, Antofagasta, Chile javiergonzalez@ucn.cl hansn@ucn.cl

CONICET, Centro de Investigaciones Paleobiológicas, Universidad Nacional de Córdoba, Av. Vélez Sarsfield 299, 5000, Córdoba, Argentina jbenedetto@arnet.com.ar

CONICET, Departamento de Ciencias Naturales, Universidad Nacional de La Pampa, Uruguay 151, 6300, Santa Rosa, Argentina ebrussa@cpenet.com.ar

\begin{abstract}
The Cordón de Lila is located immediately to the south of the Salar de Atacama, in northern Chile. The geology of the Cordón de Lila is characterized by extensive outcrops of Early Paleozoic volcanic and sedimentary rocks (Cordón de Lila Igneous and Sedimentary Complex; CISL) that form the 'Arco magmático occidental' (AMO) which is intruded by a multiple suite of Middle Ordovician to Lower Silurian granitoids. In this contribution we report the results of a sedimentological and paleontological study of a recently discovered 1,600 m thick marine Ordovician sedimentary sequence (Quebrada Grande Formation) which unconformably overlies the CISL. The Quebrada Grande Formation comprises three mayor facies associations. In stratigrafic order, these facies associations are: matrix-supported conglomerates (1), interbedded sandstones and siltstones (2) and clast-supported conglomerates (3). Facies association (1) is interpreted as debris flow deposits accumulated in a proximal marine fan-delta setting while the overlying sandstones and siltstones facies (2) represent open-marine platform deposits. Clast-supported conglomerates (3) are the record of high-energy sedimentary episodes during which coarse sediments reached the distal part of the fan-delta. The detrital fraction of the Quebrada Grande Formation is derived from the erosion of the Cambrian?-Lower Ordovician? CISL volcanic arc, the plutonic roots of the arc and its continental basement. The age of this formation is well constrained by the occurrence of brachiopods (Paralenorthis sp., Monorthis transversa Benedetto, and Mollesella? sp.) near the base and graptolites (Tetragraptus sp. and Cryptograptus? sp.) towards the middle of the succession. Both brachiopods and graptolites indicate an Arenigian to early Llanvirnian (Darriwilian) age. The brachiopod assemblage from Cordón de Lila displays affinities with the Famatina basin fauna of western Argentina. The absence of taxa in common between the AMO and the nearby 'Faja Eruptiva de la Puna Occidental' (FEPO) of NW Argentina may result from some kind of environmental barrier or some geographic separation from the Gondwana margin. According to the latter hypothesis, the Quebrada Grande succession developed on the allochtonous Arequipa-Antofalla Terrane.
\end{abstract}




\section{RESUMEN}

La Formación Quebrada Grande, del Ordovícico, Cordón de Lila (Región de Antofagasta, norte de Chile): significado estratigráfico y paleogeográfico. En el Cordón de Lila, ubicado al sur del Salar de Atacama, en la Región de Antofagasta, aflora una sucesión volcánica y sedimentaria del Paleozoico más temprano (Complejo Ígneo y Sedimentario del Cordón de Lila; CISL) que forma el 'Arco magmático occidental' (AMO), intruida por granitoides del Ordovícico medio-Silúrico inferior. En esta contribución se presenta un análisis sedimentológico y paleontológico de la recientemente reconocida Formación Quebrada Grande, una secuencia marina de ca. 1.600 $\mathrm{m}$ de espesor, que cubre, mediante discordancia angular, al CISL, y en la cual es posible definir tres asociaciones de facies que, en orden estratigráfico, son: 1) conglomerados matriz soportados, 2) intercalaciones de areniscas con lutitas y 3) conglomerados clastosoportados. La fracción detrítica deriva principalmente de la erosión del arco volcánico representado por el CISL (¿Cámbrico-Ordovícico inferior?), además de rocas plutónicas que formaron la raíz del arco, y de rocas metamórficas provenientes de su basamento continental. La facies (1), que constituye la parte inferior de la formación, se interpreta como el producto de flujos de detritos en posición proximal de un 'fan delta' marino. Las areniscas y lutitas (2), de la parte media de la formación, representan un ambiente de plataforma marina abierta. Los conglomerados clasto-soportados (3) corresponderían a flujos de alta energía que alcanzaron las partes más distales del delta. La edad de la Formación Quebrada Grande se puede precisar por la presencia de braquiópodos (Paralenorthis sp., Monorthis transversa Benedetto y Mollesella? sp.) en la base y de graptolitos (Tetragraptus sp. y Cryptograptus? sp.) en el medio de la sucesión, que indican el lapso Arenigiano-Llanvirniano inferior (Darriwiliano). La asociación de braquiópodos del Cordón de Lila presenta afinidades con las faunas de la cuenca de Famatina del oeste de Argentina. La ausencia de taxones comunes entre el AMO y la 'Faja Eruptiva de la Puna Occidental' (FEPO) del noroeste de Argentina podría deberse a algún tipo de barrera ambiental o a una separación geográfica respecto del margen de Gondwana. De acuerdo a la última hipótesis, la sucesión de Quebrada Grande podría haberse desarrollado sobre el Terrane alóctono de Arequipa-Antofalla.

Palabras claves: Ordovícico, Braquiópodos, Graptolitos, 'Terrane' de Arequipa-Antofalla, Cordón de Lila, norte de Chile.

\section{INTRODUCTION}

The Cordón de Lila is located to the south of the Salar de Atacama in northern Chile (Fig. 1). It is well known by the occurrence of important outcrops of Lower Paleozoic sedimentary, volcanic successions and intrusive rocks (Mpodozis et al., 1983; Niemeyer, 1989; Damm et al., 1990; Pérez et al., 2006; Navarro et al., 2006). The study of these units is key for the understanding of the stratigraphic, tectonic, and paleogeographic relationships between the Ordovician successions of the ArgentinaChilean Puna (Benedetto, 2001). The purpose of this paper is to discuss the age and paleobiogeographic affinities of the brachiopod and graptolite fauna of Ordovician age recently found in one of the Early Paleozoic successsions (the Quebrada Grande Formation), that crops out at Cordón de Lila (Benedetto et al., in press). In this paper, we also describe, the main facies association which, together with the study of the fossil fauna, allows the discussion of the depositional environment and the paleogeographic significance of the Quebrada Grande Formation.

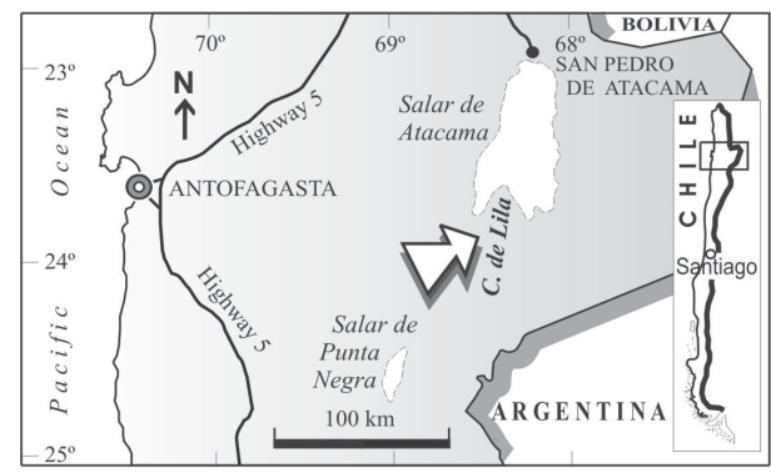

FIG. 1. Location map of Cordón de Lila in the southern part of Salar de Atacama. 


\section{PALEOZOIC GEOLOGY OF THE CORDÓN DE LILA}

The distribution of the Paleozoic lithostratigraphic units at Cordón de Lila is shown in figure 2. The oldest stratified rocks exposed in the area belong to the 'Complejo Ígneo-Sedimentario del Cordón de Lila' (CISL; Niemeyer, 1989). The lower two thirds of this approximately 3,000-m-thick succession consist of basalts interbedded with turbidites, whereas the upper third is formed mainly by rhyolitic and rhyodacitic volcanic flows with few fine grained sediment interbeds (Niemeyer, 1989; Pérez et al., 2006). The age of this complex is not well constrained and has been tentatively assigned to the Cambrian?-Lower Ordovician? on the basis of their stratigraphic relationships (Niemeyer, 1989; Damm et al., 1990). The CISL is unconformably overlain by a marine succession of about $1,600 \mathrm{~m}$

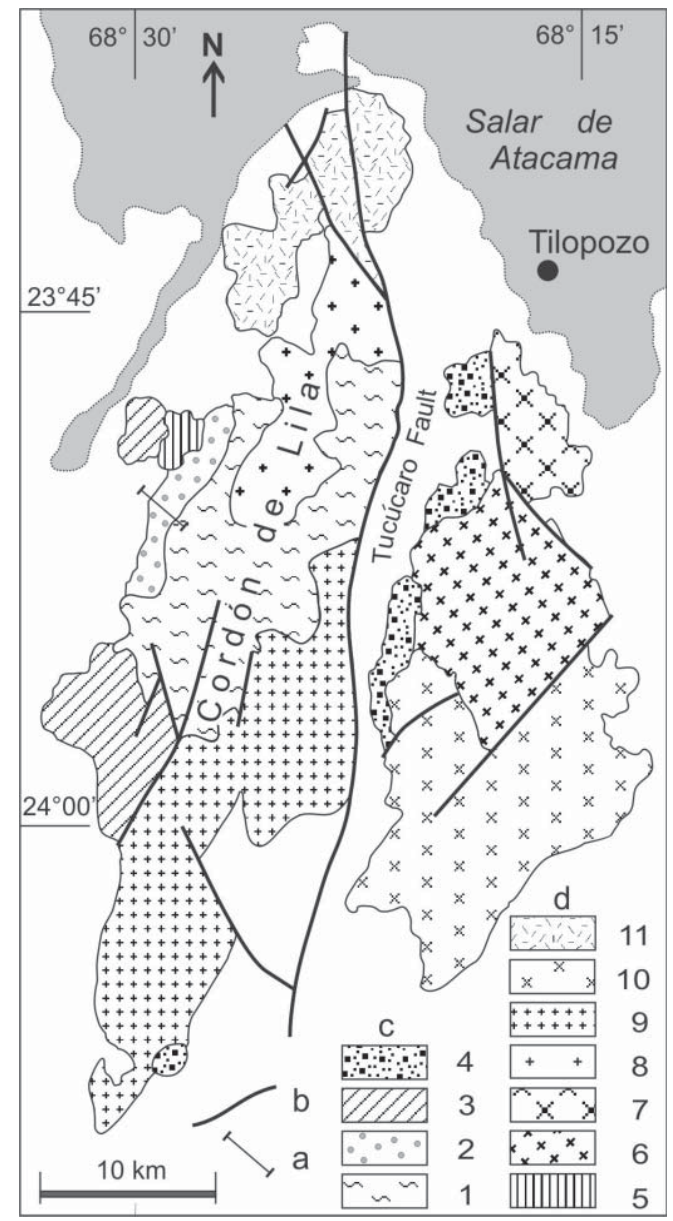

of conglomerates, sandstones and siltstones which was referred to as Quebrada Grande Formation by González et al. (2006).

The Quebrada Grande Formation is intruded by the Quebrada Ancha Porphyry, which contains conglomerate xenoliths coming from the Quebrada Grande Formation. The porphyry is in turn unconformably overlain by Lower Silurian quartzitic and calcareous sandstones of the Quebrada Ancha Formation (Navarro et al., 2006). All these rocks are intruded by huge volumes of granitic rocks of Middle-Upper Ordovician to Lower Silurian age (Mpodozis et al., 1983; Damm et al. 1990). The plutonic rocks are covered by marine quartzarenites and conglomerates of the Devonian Lila Formation (Breitkreuz, 1986).

FIG. 2. Geology of the Cordón de Lila. a- Stratigraphic section in the Quebrada Grande Formation; b- Faults; c- Stratified Paleozoic units: (1) 'Complejo Ígneo-Sedimentario del Cordón de Lila', CISL: basaltic and rhyodacitic lavas interbedded with turbidites (Cambrian?-Lower Ordovician?); (2) Quebrada Grande Formation: conglomerates, sandstones and siltstones (ArenigianLower Llanvirnian); (3) Quebrada Ancha Formation: quartzarenites and calcareous sandstones (Lower Silurian); (4) Lila Formation: quartzitic sandstones and conglomerates (Devonian); d-Plutonic Paleozoic units: (5) Feldspatic Porphyry of Quebrada Ancha (Middle Ordovician?); (6) Tilopozo Pluton: granodiorites (Upper Ordovician); (7) Tucúcaro Pluton: coarse grained granodiorites (Upper Ordovician); (8) Cerro Lila Diorite: medium to fine grained diorites (Lower Silurian); (9) Pingo-Pingo Pluton: medium grained granodiorites (Middle Ordovician); (10) Tambillo Pluton: coarse-grained granodiorites (Upper Ordovician?); (11) Granitoids (Upper Paleozoic). 


\section{LITHOLOGY AND FACIES ASSOCIATIONS}

Three mayor lithofacies associations have been recognized within the nearly 530-m-thick measured section at Quebrada Grande, which is representative of the whole section (Fig. 3): (1) matrixsupported conglomerates, (2) interbedded sandstones and siltstones and (3) clast-supported conglomerates. A number of individual lithofacies were also recognized on the basis of grain size, composition, sedimentary structures, bed configuration and geometry.

\section{MATRIX-SUPPORTED CONGLOMERATES}

This facies association, 132 m thick, occurs in the lower part of the Quebrada Grande Formation and comprises three main facies: a) Matrixsupported conglomerates, b) Clast-supported conglomerates and c) Calcareous beds.

a. Matrix-supported conglomerates dominate the association (Fig. 4a) and are typically interbedded with massive coarse-grained sandstones, calcareous beds and clast-supported conglomerates. They include poorly sorted, subangular to subrounded clasts $1-10 \mathrm{~cm}$ in diameter. Clast composition is predominantly rhyolitic to dacitic, although clasts of quartzite, schist, granodiorite and quartz are also present. The matrix is a coarsegrained sandstone that generally constitutes about $50 \%$ of the total rock volume. Bedding is tabular and wavy and the bed thickness ranges from 0.5 to $2 \mathrm{~m}$. Internally, the conglomerate beds are mostly massive, but normal to reverse and reverse to normal grading is also present.

b. Clast-supported conglomerates are a minor component of this facies association. Clasts are poorly sorted, subrounded to subangular, and range in size from pebble-cobble to boulder. The matrix is formed by coarse-grained sandstone or finepebble and constitutes less than $10 \%$ of the whole rock. Bed geometry is lenticular to tabular; thickness of individual beds ranges from 0.2 to $2 \mathrm{~m}$. There is a vertical transition to sandstones and matrixsupported conglomerates.

c. Calcareous beds. This facies includes conglomerates with calcareous cement (Fig. 4b), calcarenites, calcareous sandstones and conglomerates with calcareous cement which contains some well-preserved brachiopod shells. Calcareous beds are thin $(5-20 \mathrm{~cm})$, discontinuous and transitional to other lithologies. They are interbedded with matrix-supported conglomerates in the lowest 25 $\mathrm{m}$ of the Quebrada Grande Formation.

\section{INTERBEDDED SANDSTONES AND SILTSTONES}

This facies association, $398 \mathrm{~m}$ thick, characterizes the middle and upper part of the succession (Fig. 4c, d). It consists of alternating fine-grained sandstones and siltstones beds in packages of about 15 to $50 \mathrm{~m}$ thick, with minor matrix-supported and clast-supported conglomerates. These facies are described as follows:

- The fine-grained sandstones are composed of very fine to medium-grained sandstones in beds ranging from 0.1 to $0.2 \mathrm{~m}$ thick, with planar, wavy and lenticular geometry. Some sandstones beds display ripple marks, often of linguoid type, with average crest spacing of $8 \mathrm{~cm}$ and ripple height of approximately $1 \mathrm{~cm}$ (Fig. 4e).

- The siltstone beds are 3-10 cm thick and are finely laminated (Fig. 4f) and some contain graptolite remains.

This association is interrupted by beds of conglomerates and sandstones belonging to the associations of facies (1) and (3).

\section{CLAST-SUPPORTED CONGLOMERATES}

Clast-supported conglomerates occur throughout the succession but principally in its uppermost part in beds ranging from 2 to $40 \mathrm{~m}$ in thickness. This facies association is characterized by coarsegrained conglomerate with and without imbrication (Figs. $4 \mathrm{~g}$ and $4 \mathrm{~h}$, respectively). Clast size is commonly 2 to $5 \mathrm{~cm}$, with a maximum of $10 \mathrm{~cm}$. A minor component of this facies are clast-supported conglomerates formed by cobbles mostly ranging from 15 to $20 \mathrm{~cm}$, attaining a maximum of $60 \mathrm{~cm}$. Clasts are well sorted, rounded to subrounded, imbricate or subparallel to stratification surfaces; they are mainly rhyolitic in composition. The matrix is coarse-grained sandstone forming up to $10 \%$ of the whole rock. Beds of this facies association generally display erosive, channeled and irregular bases. 


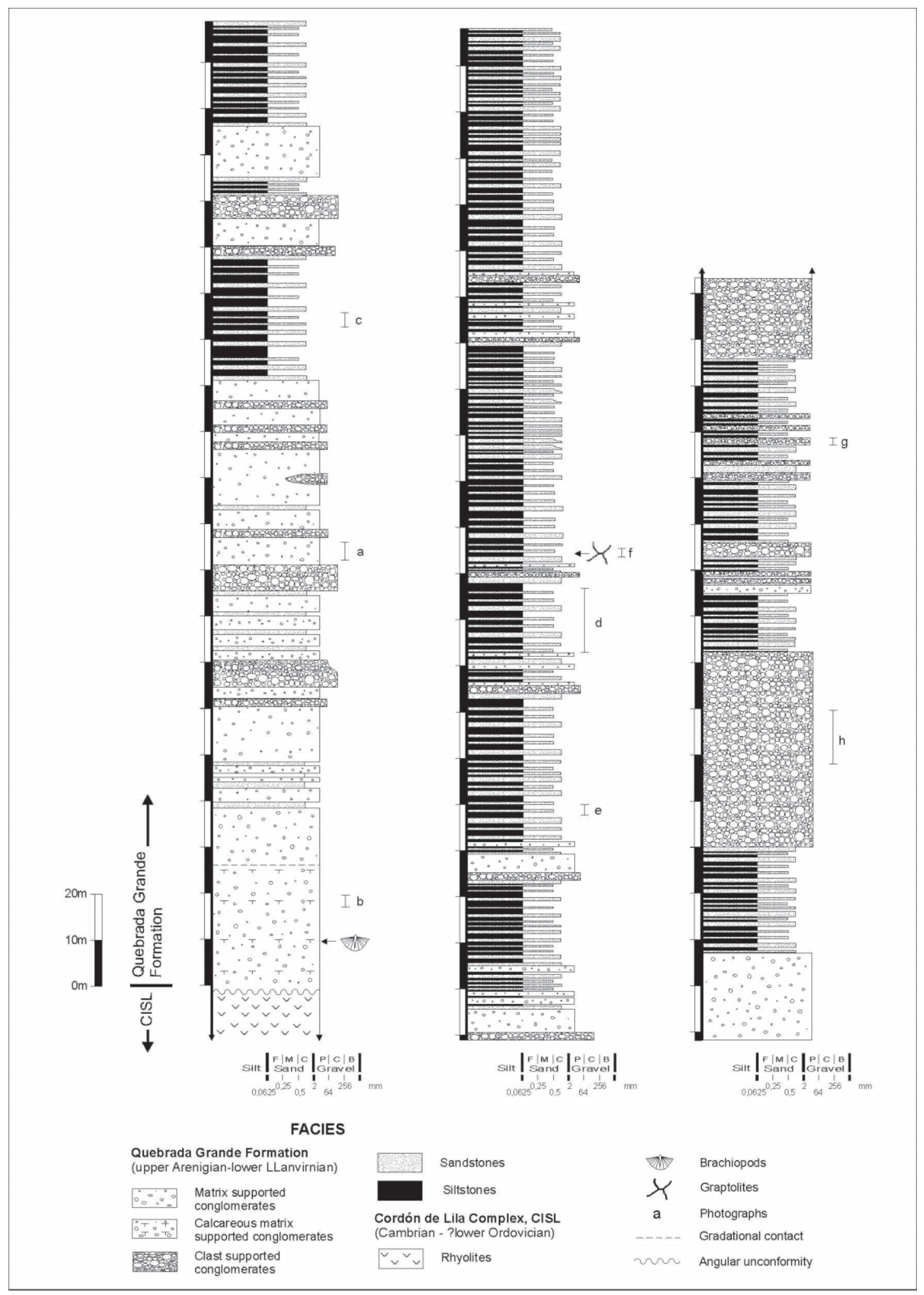

FIG. 3. Stratigraphic section of the Quebrada Grande Formation (Arenig-lower Llanvirn). The whole measured section is $593 \mathrm{~m}$ thick. Facies associations shown in figure 4 are indicated by $\mathbf{a}, \mathbf{b}, \mathbf{c}, \mathbf{d}, \mathbf{e}, \mathbf{g}$ and $\mathbf{h}$ - Levels bearing brachiopods and graptolites are also indicated. 

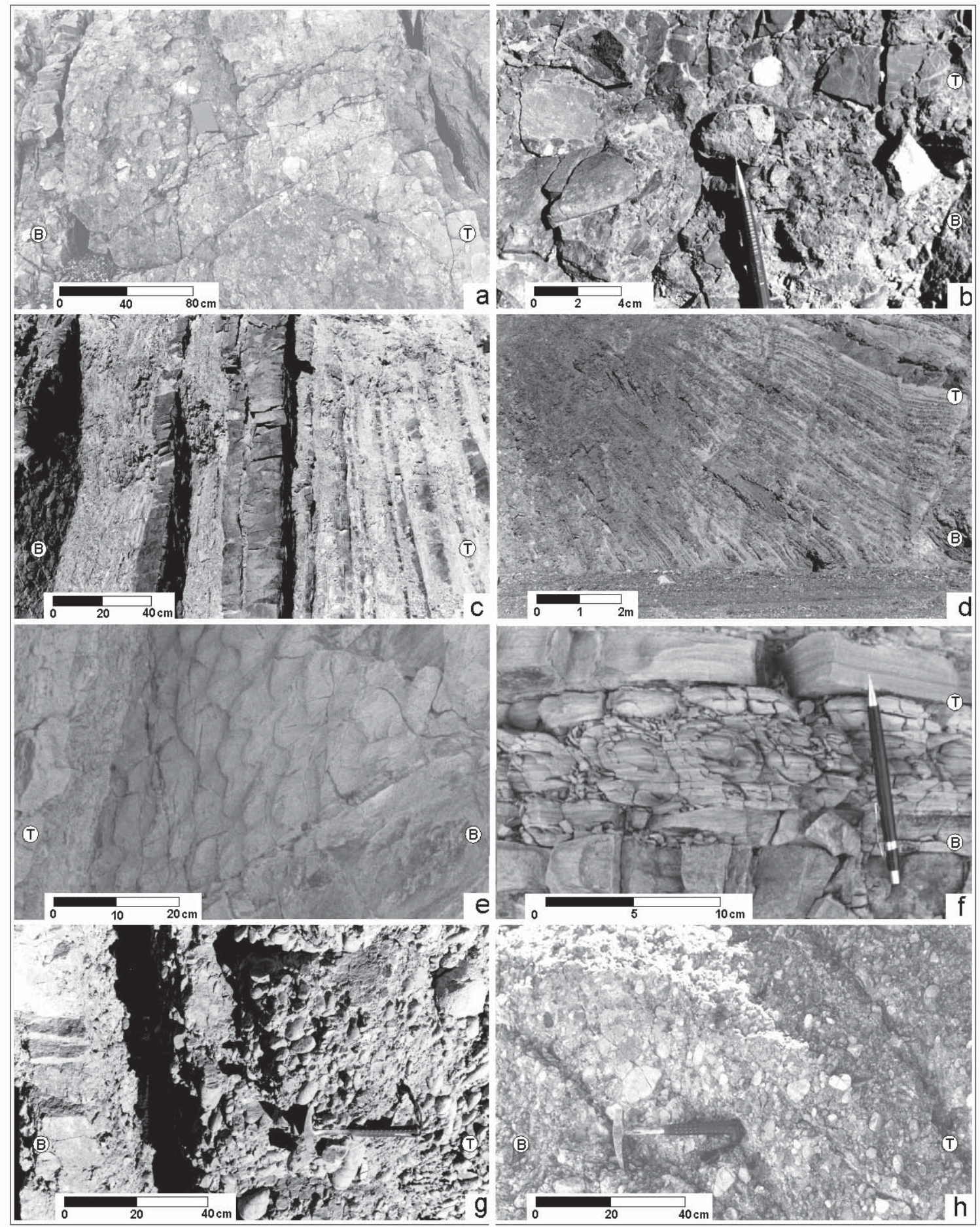

FIG. 4. Facies associations recognized in the Quebrada Grande Formation. a- Matrix- supported conglomerates; b- Calcareous matrixsupported conglomerates; c, d-Sandstones interbedded with siltstones; e- Sandstones with linguoid ripples; $\mathbf{f}$ - Siltstones containing graptolites; g- Imbricate clast-supported conglomerates; h- Non-imbricated clast-supported conglomerates. B and T indicate the base and top of the beds. 


\section{PALEOENVIRONMENTAL INTERPRETATION}

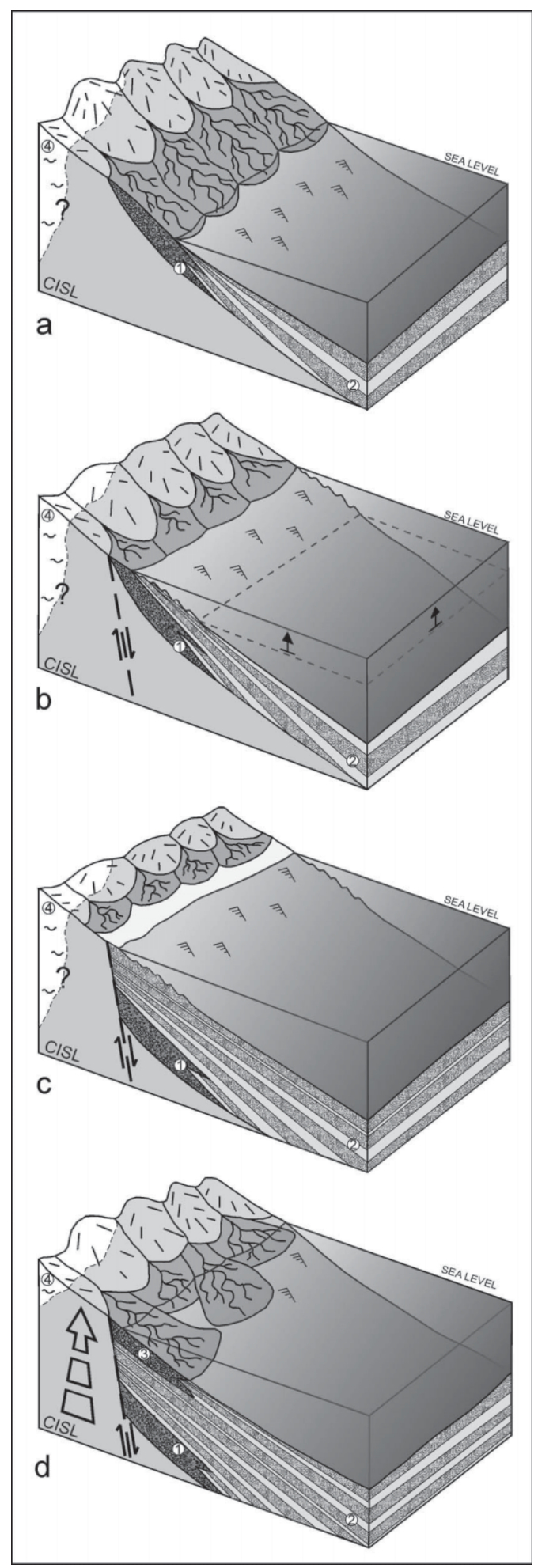

The matrix-supported conglomerates of the lower part of the Quebrada Grande Formation can be compared to the Gms facies defined by Miall (1977) in alluvial fan settings. According to Nielsen (1982), the lack of internal stratification together with the presence of reverse or reverse-to-normal grading is suggestive of debris flow deposits. Other features that suggest debris flow deposits are the occurrence of clast-supported conglomerates with poorly sorted clasts, disorganized fabric, out-sized clasts, and beds with non-erosive bases.

The thin calcareous beds probably represent episodes of low rates of detritic supply into the basin. The close relationship between the calcareous beds with marine fossils and the matrixsupported conglomerates in the lowermost $25 \mathrm{~m}$ of the succession indicate that these coarse-grained beds were deposited under subaqueous conditions. These deposits were probably shed directly into a marginal marine area forming a coastal alluvial fan (Fig. 5a; Rust and Koster, 1984). The lack of extensive reworking in the matrix-supported and calcareous beds could be explained by deposition in a protected marine embayment where fan progradation was little influenced by marine processes (Einsele, 2000), predominating fluvial over marine processes.

The abundance of fine-grained sediments, the presence of marine fossils, and the decrease of matrix-supported conglomerates towards the upper levels of the formation (sandstones-siltstones facies association) indicate sedimentation in a marine shelf environment. Fine-grained sandstones with ripple marks are interpreted as deposited above the fair weather wave base, while the finely

FIG. 5. Paleoenvironmental interpretation for the Quebrada Grande Formation. a- coastal fan delta deposits; b, c- marine platform deposits (interbedded sandstones and siltstones facies association) indicating sea level uplift by small arrows; d- Cyclic tectonic uplift of the source area (indicated by a thick arrow) and prograding of the clastsupported conglomerates in the platform. Facies associations: 1- Matrix-supported conglomerates; 2Interbedded sandstones and siltstones; 3 - Clast-supported conglomerates; 4-Basement exposed. CISL is referred to the 'Complejo Ígneo-Sedimentario del Cordón de Lila'. An hypothetical fault is shown in $\mathbf{b}, \mathbf{c}$ and $\mathbf{d}$. 
laminated siltstones beds may represent quietwater open-shelf deposits and possibly in a shoreface environment. The great thickness $(50 \mathrm{~m}$ as maximum) attained by the uppermost finegrained marine facies association suggests equilibrium between sediment supply and basin subsidence (Fig. $5 b$ and $5 c$ ).

The clast-supported (imbricate and non imbricate) conglomerates with erosive channel bases (Gm facies of Miall, 1977) are thought to represent high-energy water flow episodes that reached the more distal part of the fan (Rust and Koster, 1984). These levels are interbedded in the sandstonesiltstones packages and the absence of a gradual transition of the conglomerates with them indicate a submarine deposition and progradation of a fan delta onto the marine platform.

The overall facies distribution throughout the Quebrada Grande Formation suggests a transgressive succession starting with coastal, shallow-water fan delta deposits and finishing with open-marine shelf deposits. Nevertheless, the repetitive interbed- ding of matrix- and clast-supported conglomerates in the sandstones and siltstones facies association suggests a continuous rejuvenation of the alluvial system, probably caused by successive tectonic uplift of the source area, leading to the progradation of the coastal fan system into the sea (Fig. 5d).

Although the main rhyolitic and dacitic composition of the conglomerates clasts derived from the CISL in detriment of the more easily altered basaltic clasts suggests that the climatic factor was also important in the erosion of the volcanic arc. The linguoid ripple marks in twelve beds of the interbedded sandstones and siltstones facies association indicate a paleocurrent direction towards the west (Fig. 6a). On the other hand, clast imbrication (seven beds) and flute marks (two beds), groove marks (one bed) and erosive direccional marks (five beds) in the coastal fan facies indicate paleocurrent direction toward the south-east (Fig. $6 b)$. If the marine principal flow is assumed to be orthogonal to the coast, a nearly north-south coastalline can be inferred.
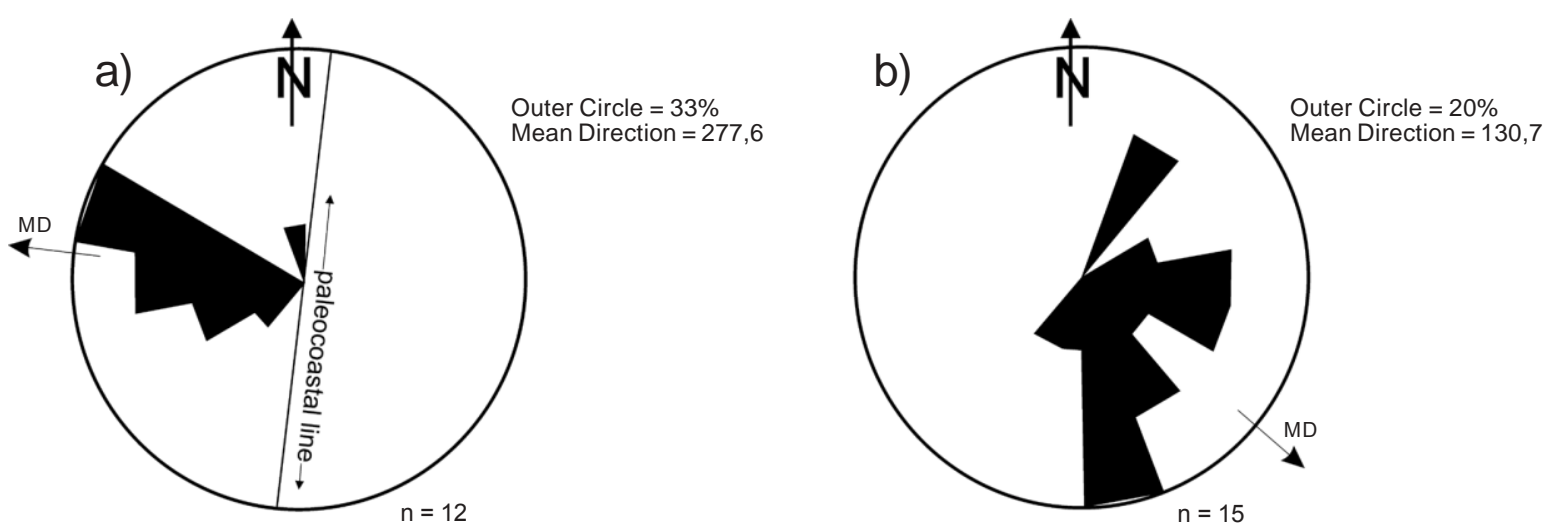

FIG. 6. Directional data from sedimentary structures. a- measurements from linguoid ripples (in interbedded sandstones and siltstone facies association); b- measurements from imbricate clast (in the clast-supported facies association).

\section{FOSSILS AND AGE}

The age of the Quebrada Grande Formation is largely based on a brachiopod assemblage recovered from the lower $25 \mathrm{~m}$ of the unit, and a single graptolite assemblage from concretions within the laminated siltstones laying approximately $300 \mathrm{~m}$ above the base of the formation (Benedetto et al.,
2005; Benedetto et al., in press). The brachiopod fauna includes Paralenorthis sp. (Fig. 7a-b), Monorthis transversa Benedetto (Fig. 7c-e), and Mollesella? sp. (Fig. 7f-g). The genus Monorthis is known from beds of Arenig and early Llanvirn age in Wales, New Brunswick, Newfoundland and 
Argentina (Neuman, 1999; Benedetto, 1998, 2003). The Quebrada Grande Monorthis specimens do not differ in any significant way from Monorthis transversa found in the volcaniclastic Molles Formation of the Famatina basin (Benedetto, 2003) and coeval rocks exposed to the north in the Rio Chaschuil area (Benedetto, 1994). In both localities the horizons bearing $M$. transversa have yielded conodonts of well-constrained Arenigian age (Albanesi and Vaccari, 1994; Lehnert et al., 1997; Albanesi and Astini, 2000). Further south, in the Precordillera basin, the San Juan Formation con- tains the species Monorthis cumillangoensis Benedetto of late Arenigian age (Benedetto, 1998, 2002). Paralenorthis is a widespread Ordovician genus mostly confined to Arenig-lower Llanvirn strata (Benedetto, 2002). A few specimens questionably referred to Mollesella Benedetto support the Arenigian age of the lower part of the Quebrada Grande Formation. The graptolites from the overlying siltstones are Tetragraptus sp. (Fig 7i) and Cryptograptus? sp. (Fig. 7h, j), that also support a late Arenig to early Llanvirn (Darriwilian) age.

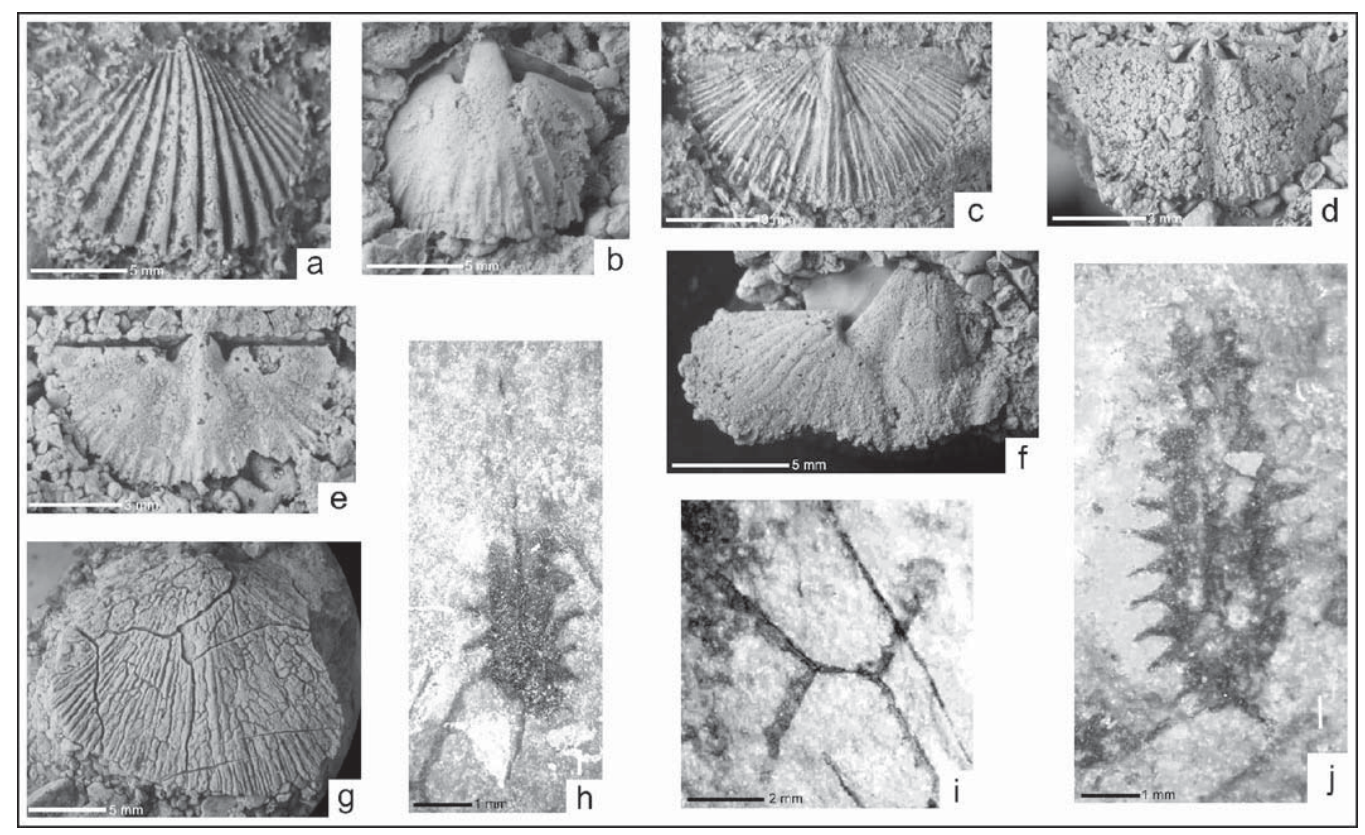

FIG. 7. Fossils from the Quebrada Grande Formation. a-b: Paralenorthis sp.; c-e: Monorthis transversa Benedetto; f-g: Mollesella? sp.; h, j: Cryptograptus? sp.; i: Tetragraptus sp.

\section{PALEOBIOGEOGRAPHIC SIGNIFICANCE}

As stated previously (Benedetto et al., in press) the record of the genus Monorthis is significant as it has been recovered elsewhere only from typical localities of the Celtic Realm (Neuman, 1976), which developed mainly at mid- to high-latitudes along the northwest Gondwana continental margins and around lapetus Ocean-related terranes, such as Avalonia and Famatina (Neuman and Harper, 1992; Benedetto, 1998, 2003). At specific level, the Cordón de Lila assemblage displays close affinities with the Famatina Range faunas of northwestern Argentina, which shares M. transversa and probably Mollesella, a genus confined to that basin. Furthermore, the species of Paralenorthis from Quebrada Grande Formation is morphologically related to $P$. brevis Benedetto, from the Famatina basin (Benedetto et al., in press). 
A striking feature is that there are no faunal elements in common between the Cordón de Lila and the Vega Pinato assemblages. Vega Pinato is a typical fossiliferous locality of the 'Faja eruptiva de la Puna occidental' located about $100 \mathrm{~km}$ eastward of Cordon de Lila. As Benedetto et al. (in press) stated, the shelly fauna recovered from the Upper Arenig exposed at Vega de Pinato is more similar to the coeval Famatina faunas. This indicates a fluid faunal exchange between the western Puna and Famatina basins, leading Benedetto (2001) to consider the western Puna volcanic rocks as the northern prolongation of the Famatina volcanic belt. Certainly, diversity of the Cordón de Lila fauna is too low to make accurate comparisons between Chilean and Argentina localities. Available evidence indicates that both, Vega Pinato and Cordón de Lila brachiopod faunas share several taxa with Famatina. Thus, the question is why the Cordón de Lila and Vega Pinato, which are located closer than the Famatina basin, do not display genera in common?

There are several possible explanations, including some degree of diachronism of the faunas, and/or the existence of some kind of barriers (environmental, geographic). Coira et al. (1999) have critically evaluated the existing chemical and age data, along with new major and trace element data, from the 'Faja eruptiva de la Puna occidental' (FEPO; Fig. 8). They included the CISL into this paleogeographic unit. Nevertheless, some authors suggested that the CISL would belong to an independent and older volcanic arc called 'Arco magmático occidental' (Omarini and Sureda, 1994) (AMO; Fig. 8). This magmatic arc has a different history, as is here demonstrated by the existence of the Quebrada Grande Formation, which has no equivalent in the FEPO. The continuity to the south of this magmatic arc could be the Choschas (Cambrian) and Alto del Inca (Lower Ordovician) plutons at Sierra de Almeida (Davidson et al., 1981; Mpodozis et al., 1983). At Sierra de Argomedo fine-grained dark clastic sedimentary rocks with volcanic intercalations containing Cruzianacf. furciferacrop out, which is characteristic of the Lower Ordovician of the Central Andes (Breitkreuz, 1985; Breitkreuz, 1986). At La Encantada a basaltic succession unconformably

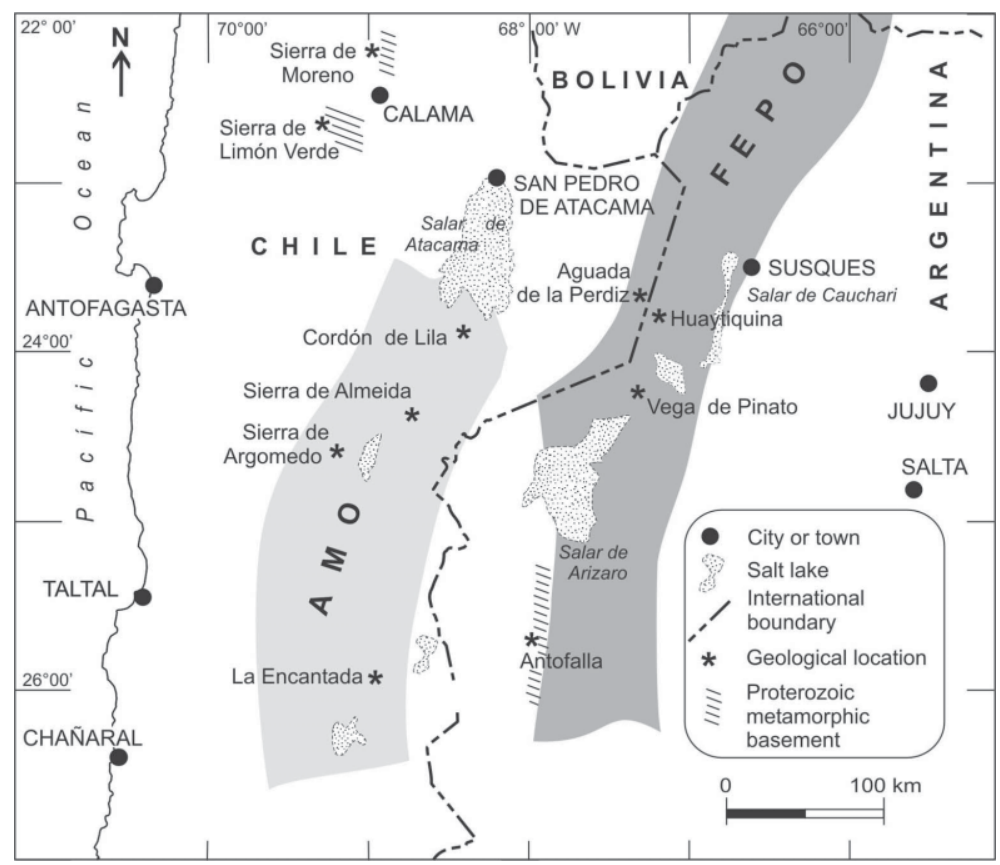

FIG. 8. Paleogeographic distribution of the 'Arco magmático occidental', AMO, and the 'Faja eruptive de la Puna occidental', FEPO in northern Chile and northwestern Argentina. 
underlies Permian limestones (personal communication of $\mathrm{C}$. Mpodozis) which has a volcanic arc geochemical character (unpublished data by one of the authors, H.N.). Consequently, and following Omarini and Sureda (1994) we consider in this contribution that the CISL would belong to an independent volcanic chain than the FEPO as known in western Argentinean Puna.

The AMO was constructed upon a continental crust, as is indicated by isotopic $\mathrm{Pb}$ composition from zircons of some of the Ordovician Plutons of Cordón de Lila (Damm et al., 1990). This fact led Bahlburg and Hervé (1997) to consider that the CISL developed upon the Proterozoic basement of the Arequipa- Antofalla Terrane, which in Chile is well exposed in the Sierra de Moreno (Loewy et al., 2004; Griem-Klee and Niemeyer, 2005; GriemKlee and Niemeyer, 2006) and Sierra de Limón Verde (Baeza-Assis, 1984), near Calama (Fig. 8).

Since the first paleomagnetic data presented by Forsythe et al. (1993), the Proterozoic rocks of northern Chile-southern Peru (the 'Arequipa-Anto- falla Massif'; Ramos, 1988) have been considered as parautochthonous with respect to Gondwana. The clockwise and counterclockwise rotation movements of this block opened and closed a small oceanic basin between this terrane and the Gondwana margin. The paleomagnetic data of Rapalini et al. (2002) suggested a latitudinal displacement of the Arequipa-Antofalla block of at least $1,000 \mathrm{~km}$ with respect to the Gondwana margin during the Ordovician. A recent synthesis by Rapalini (2005) however, stressed that the lack of well-defined Ordovician reference poles for Gondwana precludes the unambiguous determination of movements between the Arequipa-Antofalla block and Gondwana. However, he concluded that despite these uncertainties, available paleomagnetic data suggests 'some kind of relative displacement between Arequipa-Antofalla and Gondwana prior to the latest Ordovician' (Rapalini, 2005: 318). In this context, some kind of environmental barrier or some geographic separation between the AMO and the FEPO cannot be discarded.

\section{CONCLUSIONS AND DISCUSSION}

The Quebrada Grande Formation deposits represent the product of the erosion of the Cordón de Lila arc. The existence of granitic clasts in the conglomerates of the Quebrada Grande Formation suggests that the root of this complex, represented by plutons like the Choschas (Cambrian) and Alto del Inca (Lower Ordovician) (Davidson et al., 1981; Mpodozis et al., 1983; Damm et al., 1990), was exposed to erosion. Moreover, the presence of quartz and metamorphic and quartzitic pebbles in the conglomerates suggest that the continental basement upon which the volcanic arc of the CISL was constructed would have been at this time exposed to erosion. The angular unconformity between the Quebrada Grande Formation and the CISL is a mayor event in the geological evolution of the Ordovician of Cordón de Lila and show that folding observed in the latter occurred prior the upper Arenigian. The Quebrada Grande Formation evolved from shallow-water fan-delta deposits to open marine platform deposits. In this context, the prograding coastal delta coarse-grained facies of the Quebrada Grande Formation could represent the western margin of the basin developed after the and uplift of the volcanic arc represented by the CISL.

The Quebrada Grande Formation suggests that the history of the Cordón de Lila, AMO, during the Ordovician is quite different of that of the 'Faja Eruptiva de la Puna Occidental' (Palma et al., 1986), FEPO, in which sedimentation is nearly continuous from the Tremadocian at Huaytiquina (Monteros etal., 1996; Moya et al., 1993; Koukharsky et al., 1996) to the Late Llanvirn in Aguada de la Perdiz and neighbouring outcrops (Pérez, 1983; Gardeweg and Ramírez, 1985). The lack of affinity between brachiopods from Cordón de Lila and localities further east remains unclear, but the possibility that the Cordón de Lila could belong to the Arequipa-Antofalla Terrane cannot be discarded. Available faunal evidence, however, is compatible with both autochthonous or parautochthonous scenarios, and the allochthony of the Cordón de Lila needs to be demonstrated by further evidence. 


\section{ACKNOWLEDGMENTS}

$\mathrm{H}$. Niemeyer acknowledges financial support of the Dirección de Investigaciones y Postgrados of the Universidad Católica del Norte. J.L. Benedetto and E.D. Brussa acknowledge funding by CONICET (Grant PIP CONICET 5599) and Agencia Nacional de Promoción Científica y Tecnológica PICT 21857 and Universidad Nacional de La Pampa. Dr. K. Grove of the San Francisco State University (USA) reviewed the sedimentology of this paper. The authors thank C. Mpodozis (ENAP, Chile), P. Isaacson (University of Idaho, USA) and E. Villas (Universidad de Zaragoza, España) for their reviews of this paper. We thank L. Jofré (Universidad Católica del Norte, Chile) for drafting some of the figures of this contribution.

\section{REFERENCES}

Albanesi,G.L.; Vaccari, N.E. 1994. Conodontos del Arenig en la Formación Suri, Sistema de Famatina, Argentina. Revista Española de Micropaleontología 26: 125146.

Albanesi,G.L.; Astini, R.A. 2000. New conodont fauna from Suri Formation (Early-Middle Ordovician), Famatina System, western Argentina. In Reunión Anual Comunicaciones Asociación Paleontológica Argentina. Abstracts: 3. Mar del Plata.

Baeza-Assis, L. 1984. Petrography and tectonics of the Plutonic and Metamorphic Complexes of Limón Verde and Mejillones Peninsula, Northern Chile. Doctorate Thesis (Unpublished), Tübingen Universität: $205 \mathrm{p}$.

Bahlburg, H.; Hervé, F. 1997. Geodynamic evolution and tectonostratigraphic terranes of northwestern Argentina and northern Chile. Geological Society of America Bulletin 109 (7): 869-884.

Benedetto, J.L. 1994. Braquiópodos ordovícicos (Arenigiano) de la Formación Suri en la región de Chaschuil, Sistema de Famatina, Argentina. Ameghiniana 31: 221-238.

Benedetto, J.L. 1998. Early Paleozoic brachiopods and associated shelly faunas from western Gondwana: their bearing on the geodynamic history of the preAndean margin. In The Proto-Andean Margin of Gondwana (Pankhurst, R.; Rapela, C.W.; editors). Geological Society Special Publications 142: 57-83. London.

Benedetto, J.L. 2001. Una fauna de braquiópodos arenigianos (Ordovícico temprano) en rocas volcaniclásticas de la Puna occidental: Implicaciones paleoclimáticas y paleogeográficas. Ameghiniana 38: $131-146$

Benedetto, J.L. 2002. The Ordovician brachiopod faunas of Argentina: chronology and biostratigraphic succession. In Aspects on the Ordovician System in Argentina (Aceñolaza, F.G.; editor). Instituto Superior de Correlación Geológica (INSUGEO), Serie Correlación Geológica 16: 87-106.
Benedetto, J.L. 2003. Early Ordovician (Arenig) brachiopods from volcaniclastic rocks of the Famatina Range, northwest Argentina. Journal of Paleontology 77 (2): 212-242.

Benedetto, J.L.; Niemeyer, H.; González, J.; Brussa, E.D. 2005. First occurrence of Ordovician brachiopods and graptolites from Cordón de Lila (Salar de Atacama), northern Chile: stratigraphic and paleobiogeographic implications. In Gondwana 12, Geological and Biological Heritage of Gondwana (Pankhurst, R.J.; Veiga, G.D.; editors), Abstracts: 68.

Benedetto, J.L.; Niemeyer, H.; González, J.; Brussa, E.D. In press. Primer registro de braquiópodos y graptolitos en el Cordón de Lila (Puna de Atacama), norte de Chile. Ameghiniana.

Breitkreuz, C. 1985. Presentation of a marine volcanosedimentary sequence of presumably Pre-Devonian age in the Sierra de Argomedo $\left(24^{\circ} 45^{\prime} \mathrm{S}-69^{\circ} 22^{\prime} \mathrm{W}\right)$, Northern Chile. In Congreso Geológico Chileno, No. 4, Actas 1: 76-88. Antofagasta.

Breitkreuz, C. 1986. Das Paläeozoikum in den Kordilleren Nordchiles $\left(21^{\circ}-25^{\circ} \mathrm{S}\right)$. Geotektonische Forschungen, 70 (I-II): 88 p. Stuttgart.

Coira, B. L.; Kay, S. Mahlburg; Pérez, B.; Hanning, M.; Flores, P. 1999. Magmatic sources and tectonic setting of Gondwana margin Ordovician magmas, northern Puna of Argentina and Chile. In LaurentiaGondwana Connections before Pangea (Ramos, V.A.; Keppie, J.D.; editors). Geological Society of America Special Paper 336: 145-170.

Damm, K.W.; Pichowiak, S.; Harmon, R.S.; Todt, W.; Kelley, S.; Omarini, R.; Niemeyer, H. 1990. PreMesozoic evolution of the central Andes: The basement revisited. In Plutonism from Antarctica to Alaska (Kay, S.M.; Rapela, C.W.; editors). Geological Society of America, Special Paper 241: 101-126.

Davidson, J.; Mpodozis, C.; Rivano, S. 1981. El Paleozoico de Sierra de Almeida, al oeste de Monturaqui, Alta Cordillera de Antofagasta, Chile. Revista Geológica de Chile 12: 3-23. 
Einsele, G. 2000. Sedimentary basins: evolution, facies and sediment budget. Springer-Verlag: $792 \mathrm{p}$.

Forsythe, R.; Davidson, J.; Mpodozis, C.; Jesinkey, Ch. 1993. Lower Paleozoic relative motion of the Arequipa block and Gondwana: paleomagnetic evidence from Sierra de Almeida of Northern Chile. Tectonics 12 (1): 219-236.

Gardeweg, M.; Ramírez, C.F. 1985. Hoja Río Zapaleri. II Región de Antofagasta. Servicio Nacional de Geología y Minería, Carta Geológica de Chile, 66: 89 p., 1 mapa escala 1:250.000.

González, J.; Niemeyer, H.; Benedetto, J.L.; Brussa, E.D. 2006. La Formación Quebrada Grande, Arenigiano superior-Llanvirniano inferior del Cordón de Lila, Región de Antofagasta, Norte de Chile. In Congreso Geológico Chileno, No.11, Actas 1: 49-52. Antofagasta.

Griem-Klee, S.; Niemeyer, H. 2005. Provenance and age of metasedimentary basement rocks exposed in the Sierra de Moreno, northern Chile ( $\left.21^{\circ} 30^{\prime} \mathrm{S}, 68^{\circ} 50^{\prime} \mathrm{W}\right)$ : preliminary results. In Gondwana 12 Conference, Geological and Biological Heritage of Gondwana (Pankhurst, R.J.; Veiga, G.D.; editors), Abstracts: 184. Mendoza.

Griem-Klee, S.; Niemeyer, H. 2006. Estilo de deformación pre-mesozoica de rocas del basamento en el sector Quebrada Sama ( $\left.21^{\circ} 30^{\prime} S, 68^{\circ} 50^{\prime} \mathrm{W}\right)$, Sierra de Moreno, Norte de Chile. In Congreso Geológico Chileno, No. 11, Actas 1: 233-236. Antofagasta.

Koukharsky, M.; Torres Claro, R.; Etcheverría, M.; Vaccari, N.E.; Waisfeld, B.G. 1996. Episodios volcánicos del Tremadociano y Arenigiano en Vega Pinato, Puna salteña, Argentina. In Congreso Geológico Argentino, No. 13, Actas 5: 535-542. Buenos Aires.

Lehnert, O.T.; Bergström, S.M.; Vaccari, N.E. 1997. Arenig conodonts from the Famatina Range, northwestern Argentina: faunal affinities and paleogeographic implications. In International Association Sedimentologists (IAS), Regional European Meeting of Sedimentology, Gaea Heidelbergensis, No. 18, Vol. 3: 216.

Loewy, S.L.; Connely, F. N.; Dalziel, I.W.D. 2004. The Arequipa-Antofalla Basement of the central Andean margin of South America. Geological Society of America Bulletin 116 (1-2): 171-187.

Miall, A.D. 1977. A review of the braided-river depositional environment. Earth Science Reviews 13: 1-62.

Monteros, J.A.; Moya, M.C.; Monaldi, C.R. 1996. Graptofaunas arenigianas en el borde occidental de la Puna argentina. Implicancias paleogeográficas. In Congreso Geológico de Bolivia, No. 12, Memorias: 733-746. Tarija.

Moya, M.C.; Malanca, S.; Hongn, F.; Bahlburg, H. 1993. El Tremadoc temprano en la Puna Occidental argentina. In Congreso Geológico Argentino, No. 12, Actas 2: 20-30. Mendoza.
Mpodozis, C.; Hervé, F.; Davidson, J.; Rivano, S. 1983. Los granitoides de Cerros de Lila, manifestaciones de un episodio intrusivo y termal del Paleozoico inferior en los Andes del Norte de Chile. Revista Geológica de Chile 18: 3-14.

Navarro, A.; Niemeyer, H.; Boucot, A.; Aceñolaza, F.G. 2006. El Silúrico del Cordón de Lila, Región de Antofagasta, Chile. In Congreso Geológico Chileno, No. 11, Actas 1: 85-92. Antofagasta.

Neuman, R.B. 1976. Early Ordovician (late Arenig) brachiopods from Virgin Arm, New World Island Newfoundland. Geological Survey of Canada Bulletin 261: 11-61.

Neuman, R.B. 1999. Arenig-Early Llanvirn age Celtic brachiopod assemblage reaffirmed. In Quo vadis Ordovician? (Kraft, P.; Fatka, O. editors). Acta Universitatis Carolinae, Geologica 43 (1-2): 345-346.

Neuman, R.B.; Harper, D.A.T. 1992. Paleogeographic significance of the the Arenig-Llanvirn Toquima-Table Head and Celtic brachiopod assemblages. In Global Perspectives on Ordovician Geology (Webby, B.D.; Laurie J.; editors). Balkema: 241-254. Rotterdam.

Nielsen, T.H. 1982. Alluvial fan deposits. In Sandstones depositional environments (Scholle, P.A.; Spearing, D.R.; editors). American Association of Petroleum Geologist, Memoir 31: 49-86.

Niemeyer, H. 1989. El Complejo ígneo-sedimentario del Cordón de Lila, Región de Antofagasta: significado tectónico. Revista Geológica de Chile 16 (2): 163-181.

Omarini, R.H.; Sureda, R.J. 1994. El basamento centroandino y sus cuencas marginales entre el rift irúyico (515 Ma) y la colisión oclóyica (435 Ma). In Congreso Geológico Chileno, No. 7, Actas 1: 491497. Concepción.

Palma, M.A.; Parica, P.D.; Ramos, V.A. 1986. El granito Archibarca: su edad y significado tectónico, Provincia de Catamarca. Revista de la Asociación Geológica Argentina 41: 414-419.

Pérez, A.; Niemeyer, H.; Zimmermann, U. 2006. Estratigrafía, petrografía y geoquímica de la parte superior del Complejo ígneo-sedimentario Cordón de Lila. In Congreso Geológico Chileno, No. 11, Actas 2: $527-$ 530. Antofagasta.

Pérez d' A., E. 1983. Estado actual del conocimiento del Cambro-Ordovícico en Chile. In Desarrollo del Cámbrico y Ordovícico de Latinoamérica, Segunda reunión del Grupo Internacional Programa Internacional de Correlación Geológica (PICG): 88-97. Cartagena de Indias.

Ramos, V.A. 1988. Late Proterozoic-Early Paleozoic of South America: a collisional history. Episodes 11: 168-174.

Rapalini, A.E. 2005. The accretionary history of southern South America from the latest Proterozoic to the late Palaeozoic: some palaeomagnetic constraints. In Terrane Processes at the Margins of Gondwana (Vaughan, A.P.M.; Leat, P.T.; Pankhurst, R.J.; 
editors). Geological Society Special Publications 246: 305-328. London.

Rapalini, A.E.; Velasco, M.S.; Koukharsky, M. 2002. New paleomagnetic data from the western Puna of Argentina: some tectonic speculations on its Early
Paleozoic evolution. In International Symposium on Andean Geodynamics, No. 5: 505-508. Toulouse.

Rust, B.R.; Koster, E.H. 1984. Coarse Alluvial Deposits. In Facies Models, second edition (Walker, R.; editor). Geoscience Canada: 53-69. 